УДК 378.147

DOI: https://doi.org/10.24919/2308-4634.2021.236240

Марія Шмир, доктор педагогічних наук, доиент, доцент кафедри іноземних мов та методик їх навчання Кременецької обласної гуманітарно-педагогічної академії імені Тараса Шевченка

\title{
САМОСТІЙНА РОБОТА СТУДЕНТІВ У КОНТЕКСТІ ДІЯЛЬНІСНОГО ПІДХОДУ В НАВЧАННІ
}

Стаття присвячена актуальній проблемі, реалізачія якої сприяє забезпеченню формування у випускників закладів вищої освіти здатності навчатися упродовж життя. За иих умов, підкреслюсться у статті, особливої актуальності набуває залучення студентів до самостійної роботи.

Наукова новизна дослідження полягає у розкритті особливостей організаиії самостійної роботи студентів у контексті діяльнісного підходу, реалізація якого грунтується на основі розробленої функційноструктурної дидактичної системи, що передбачає активацію процесів самомотивації, самоорганізації, самодіяльності, самоуправління, самоконтролю самоочінки і саморефлексї в інформаційно-освітньому середовищі закладу вищої освіти.

Означені результати проведеного дослідження, щь вказуються у статті, засвідчують позитивні зміни у формуванні здатності до самовдосконалення, саморозвитку.

Ключові слова: функційно-структурна дидактична система; діяльнісний підхід; саморозвиток; самовдосконалення.

Puc. 2. Лim. 8.

Mariya Shmyr, Doctor of Sciences (Pedagogy), Associate Professor, Associate Professor of the Foreign Languages and Methods of Teaching Department Kremenets Regional Humanitarian and Pedagogical Academy named after Taras Shevchenko

\section{INDEPENDENT WORK OF STUDENTS IN THE CONTEXT OF ACTIVITYTEACHING APPROACH}

The article is devoted to a topical issue, the implementation of which contributes to the formation of graduates' ability to learn throughouttheir life.Under these conditions, as it is emphasized in the article, the involvement of students in independent work becomes especially important.

Numerous works of prominent scientists are devoted to various aspects of independent work, which underlines the importance and significance of this problem.

The purpose of the article is to substantiate the peculiarities of the organization of independent work of students of higher educational institutions in the context of the activity approach in its new vision.

Methods. Theoretical, empirical and statistical methods were used in the study.

Results. The emphasis is placed on the importance of independent work, it has been outlined that it is based on activities, and therefore, the methodological basis for the organization of independent work of students is the activity approach to learning. The activity approach is considered in the article as a certain mechanism for achieving this goal. Like every mechanism, the activity approach functions on the basis of a certain system and under certain conditions. The model of functional-structural didactic system is outlined, the fundamental basis of which is the created taxonomy of didactic conditions of realization of the activity approach.

This system has a significant didactic potential for the organization of independent work of students.

Special attention was paid tothe selection of content for independent work, methods and techniques of involving students in certain activities.

Originality.The scientific novelty of the study is to reveal the features of the organization of independent work of students in the context of the activity approach, the implementation of which is based on the developed functional-structural didactic system, which provides activation of self-motivation, self-organization, self-employment, self-management, selfcontrol of self-esteem and self-reflection in the information and educational environment of higher education.

Conclusion. These results of the study, indicated in the article, show positive changes in the formation of the ability to self-improvement, self-development.

Prospects for further research are seen in the development of new conceptual aspects of the organization of independent work of students.

Keywords: functional-structural didactic system, activity approach, self-development, self-improvement. 
поповнювати і розширювати свої знання, оперативно реагувати на вимоги процесу розвитку науки і техніки. Тому сьогодні особливістю освітнього процесу у ЗВО є формування у випускників здатності навчатися протягом життя. За цих умов актуалізується потреба залучення студентів до самостійної роботи, що є основою цілеспрямованості і саморозвитку.

Аналіз наукових досліджень. Аналіз педагогічних досліджень дає можливість стверджувати, що вищою школою набутий багатий досвід в питаннях дослідження різних аспектів самостійної роботи студентів. Розвиток пізнавальної самостійності досліджували: А. Алексюк, Г. Костюк, О. Конопкін, О. Малихін, О. Мороз, А. Молибог, О. Скрипченко, Н. Сидорчук, В. Онищук та ін. Розвиток самостійності, в позааудиторній діяльності висвітлювали О. Дубасюк, Я. Клименко, В. Лозова, М. Лубинець, Л. Онищук та ін. С. Вітвицька, І. Зимня, А. Калашник, Л. Кнодель, А. Кузьмінський, 3. Курлянд, О. Малихін, В. Нагаєв, П. Підкасистий розкривали у своїх працях різні підходи до класифікації самостійної роботи. О. Аксьонова, В. Свдокимова, Л. Кочина, Г. Сіданіч, М. Солдатенко, I. Шимко акцентують увагу на
Самостійна робота грунтується на діяльності як основному принципу навчання. Діяльність $€$ складною системою, яку утворюють: предмет, потреба, мета, активність тощо. Між названими компонентами існує зв'язок. Діяльність відбувається тоді, коли є потреба. Сама собою потреба не викликає свідомої діяльності. Для іiі виникнення необхідне співвіднесення потреби 3 предметом, за допомогою чого іiі можна задовольнити. У нашому дослідженні потреба в знаннях, уміннях і навичках спрямовується на предмет - фахові дисципліни і різні види педагогічної практики. Усвідомлена потреба стає мотивом поведінки. Для суб'єкта мотив постає як безпосередня спонукальна сила. В узагальненому плані мотив - це відображення потреби, що діє як об’єктивна закономірність і виступає як об'єктивна необхідність. В мотивах “викристалізовується” конкретна мета. Усвідомлена мета - це активність [7, 17-18].

У структурі активності виділяємо такі компоненти: готовність виконувати завдання, свідомість виконання завдань, систематичність навчання, прагнення підвищити особистісний рівень тощо.

\begin{tabular}{|l|l|l|l|}
\hline \multicolumn{4}{|c|}{ Активність - усвідомлена мета } \\
\hline \multicolumn{2}{|c|}{ Основні компоненти активності } \\
\hline $\begin{array}{l}\text { Готовність виконувати } \\
\text { завдання }\end{array}$ & $\begin{array}{l}\text { Свідомість виконання } \\
\text { завдань }\end{array}$ & $\begin{array}{l}\text { Систематичність } \\
\text { навчання }\end{array}$ & $\begin{array}{l}\text { Прагнення підвищити } \\
\text { особистісний рівень }\end{array}$ \\
\hline
\end{tabular}

Рис. 1. Структура активності

ролі викладача в організації самостійної роботи. Велика кількість праць, в яких розглядаються різні аспекти самостійної роботи студентів, розкривається ㄲï значущість, засвідчує багатогранність досліджуваної проблеми. Наукові доробки вчених слугують важливим підгрунтям для нашої розвідки, що грунтується на застосуванні діяльнісного підходу в організації самостійної роботи у процесі підготовки вчителя іноземної мови.

Постановка завдання. Мета статті полягає в обгрунтуванні особливостей застосування діяльнісного підходу в організації самостійної роботи у процесі підготовки вчителя іноземної мови.

Виклад основного матеріалу. Самостійна робота має значний дидактичний потенціал. Вона здатна поглиблювати, розширювати, систематизувати знання, формувати інтерес до пізнавальної діяльності, виробляти прийоми пізнання, розвивати пізнавальні здібності, виховувати відповідальність $[3,20-22]$.
Відрізняють внутрішню і зовнішню активність. Систематичність навчання, прагнення підвищити особистісний рівень спричиняють внутрішню активність, що спонукає студентів до виконання самостійної роботи.

Як зазначалося раніше, спонукальною силою до саморозвитку є мотивація навчання, компоненти якої стимулюють дію для протікання розумових процесів, створюють внутрішні умови розвитку прагнення до самоосвіти, мобілізують творчі сили для пошуку і розв'язання навчальних завдань [5, 28-30].

Окреслене вище вказує на те, що прояв елементів діяльності забезпечує реалізацію самостійної роботи.

Оскільки пізнавальна діяльність грунтується на діяльнісній теорії навчання, то методологічною основою студентів є діяльнісний підхід у навчанні.

Діяльнісний підхід ми розглядаємо як певний механізм реалізації поставленої мети. Кожен механізм функціонує на основі певної системи і при певних умовах. Отже, і діяльнісний підхід функціонує на основі відповідної системи. 


\section{САМОСТІЙНА РОБОТА СТУДЕНТІВ У КОНТЕКСТІ ДІЯЛЬНІСНОГОПІДХОДУ В НАВЧАННІ}

У пропонованій статті спираємося на розроблену нами під керівництвом професора О. Малихіна модель функційно-структурної дидактичної системи, котра грунтується на чотирьох взаємопов'язаних компонентних конструктах, а саме: концептуально-дидактичному, змістово-дієвому, функційно-дієвому та рефлексійно-діяльнісному. Кожен із названих конструктів включає субконструкти, а саме: концептуально-дидактичний: методологічний, теоретичний, технологічний, психологодидактичний; змістово-дієвий: організаційнодієвий та когнітивно-структурний субконструкти; функційно-дієвий конструкт включає субконструкт мотивації діяльності майбутнього вчителя та інструментально-діяльнісний субконструкти; до рефлексійно-діяльнісної входять: діагностувальноінструментальний, компетентнісно-верифікаційний та аналітико-статистичний субконструкти. Із зазначеного вище видно, що означена система охоплює різні аспекти навчання і містить значний дидактичний потенціал для організації і здійснення самостійної роботи. Вектор діяльності, згідно даної системи спрямований на залучення студентів до різних видів самостійної діяльності, самодіяльності, самоуправління $[8,23]$.

Концептуально-дидактичний конструкт передбачає визначення дидактичних основ реалізації діяльнісного підходу в організації самостійної роботи студентів та надає розуміння на науково-педагогічному рівні сутності активації процесів самомотивації, самоорганізації, самооцінки, самоконтролю та саморефлексії в інформаційно-освітньому середовищі сучасного закладу вищої освіти.

Великого значення надаємо змісту матеріалу для самостійної роботи, важливим елементом якого є обсяг знань, що становлять його фундамент. Досить образно про це говорив Я. Коменський: “архітектор, плануючи побудувати міцну будівлю, заготовляє не солому, не болото, не лозу, а каміння, цеглу, міцне дерево і тому подібний матеріал. А садівник, який “бажає, щоб поле, виноградник, сад давали плоди, засіває їх не бур'янами, не кропивою, не чортополохом, а благородним насінням і рослинами" [2, 272]. Ми намагаємося підбирати зміст матеріалу для самостійної роботи, щоб він віповідав потребам та інтересам студентів. В опануванні змісту навчальних дисциплін, за переконливим твердженням відомого вченого А. Леонтьєва, вирішальне значення має те, яке місце в житті людини займає саме знання: чи дійсно воно $\epsilon$ частиною їі життя, чи лише зовнішньо нав'язане. Щоб знання не були формально засвоєні, треба не “відбувати” навчання, а “прожити” його: потрібно, щоб навчання увійшло в життя, щоб воно мало життєвий сенс для учня" $[4,12]$. Отже, особистісна значущість змісту, його відповідність потребам й інтересам студентів є однією 3 найважливіших умов, що спонукають до активності у засвоєнні знань. Підбір змісту допомагає забезпечити такі аксіологічні відносини: студент - зміст, за яких він виступає не як щось зовнішньо задане, а те, що внутрішньо спонукає до його засвоєння. Саме тому при відборі змісту матеріалу для самостійної роботи потрібно “із сирої руди вибрати крупинки золота, оскільки не так важливий обсяг знань, як їх цінність" $[1,34]$.

Однак предметні знання і вміння є лише засобом самопізнання, а саморозвиток

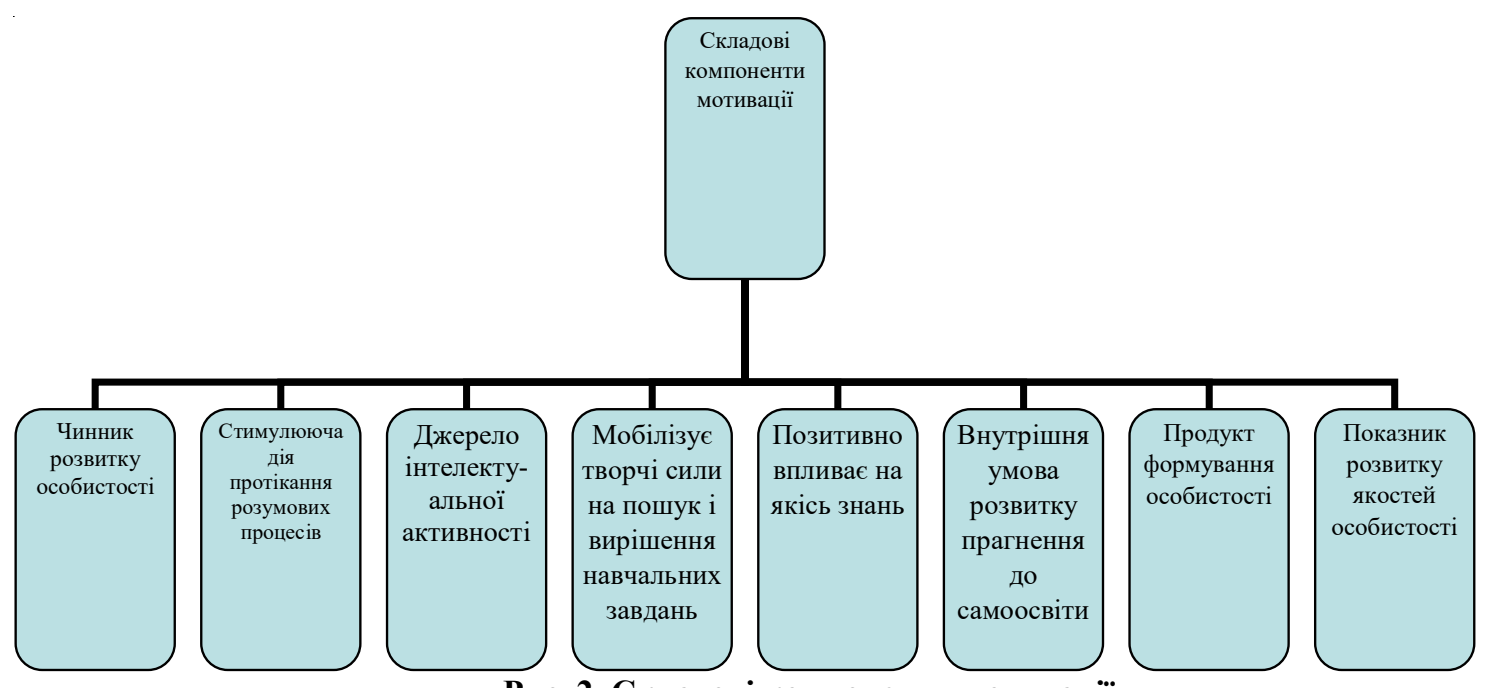

Рис. 2. Складові компоненти мотивації 


\section{САМОСТІЙНА РОБОТА СТУДЕНТІВ У КОНТЕКСТІ ДІЯЛЬНІСНОГО ПІДХОДУ В НАВЧАННІ}

особистості неможливий без його активної діяльності.

В організації самостійної роботи студентів акцентується увага на тому, що вони повинні не тільки засвоювати матеріал, а й осмислювати себе самого і свої взаємини зі світом, визначати мету і способи діяльності. При цьому мета - не тільки “Що потрібно засвоїти? А й для чого? Як? Який смисл засвоєння?"

Отже, в особистісно зорієнтованій парадигмі вектор діяльності спрямовується на пізнання суб'єктом самого себе, процесу взаємодії із світом і смислу власної діяльності [6, 29-44]. Це підтверджує взаємозв'язок діяльнісного і особистісно зорієнтованого підходів, що забезпечує спрямованість діяльності на саморозвиток, самостійність, самопізнання.

Залучаючи студентів до самостійної роботи, намагаємось орієнтувати їх на засвоєння не чужих думок, не тільки на знання, а на дії на основі цих знань. Ще відомий Епікур свого часу виголошував думку про те, що найголовнішою ознакою повного знання $є$ уміння швидко користуватися набутими знаннями на практиці. Один із афоризмів твердить: знання - це ще не мудрість, мудрість - це застосування знань. Дуже важливо працювати з логічною структурою знань. Щоб отримана студентами на заняттях інформація перетворилася у знання, студенти повинні зрозуміти їі суть, добре осмислити. Г. Спенсер говорив, що “не те знання цінне, яке накопичується у вигляді розумового жиру а те, яке перетворюється на розумові мускули".

Значення самостійної роботи в навчанні можна підтвердити поетичними рядками поета М. Рилєнкова: "Хоть выйди ты не в белый свет, а в поле за околицу. Пока ты шел за кем-то вслед, дорога не запомнится. А вот, куда б ты не попал, и по какой распутице, дорога та, что сам искал, вовек не позабудется".

В обсязі знань, які студенти отримують в процесі самостійної роботи, ми виділяємо знання теоретичного характеру (типу “Що?”) і практичного (типу “Як?”), тобто описові знання і знання про способи діяльності. Різницю можна продемонструвати такими висловами: "По справжньому знає камінь не той, хто його роздобув і пізнав таємницю структури, а той, хто 3 нього храм побудував”. "Коли ви даєте голодній людині рибу, вона буде сита лише один день, а коли ви навчите їі ловити рибу, вона буде сита все своє життя” $[1,27]$.

Другим важливим компонентним конструктом реалізації діяльнісного підходу у процесі залучення студентів до самостійної роботи є функційно- дієвий конструкт, який передбачає визначення й інтенсифікацію діяльнісного спрямування інноваційних освітніх технологій на основі врахування досвіду класичних дієорієнтованих форм організації, методів, прийомів і засобів навчання та їхньої інтеграції з інтерактивними методами навчання із застосуванням сучасних IT-технологій.

Не менш важлива роль належить рефлексійнодіяльнісному компонентному конструкту, оскільки він сприяє переходу контролю в самоконтроль, оцінки - в самооцінку, що забезпечує осмислення студентом власних дій, тобто рефлексії.

Діяльнісний підхід, як зазначалося вище, реалізується на основі розглянутої системи, фундаційною основою ефективного функціонування якої $є$ вияв і створення таксономії організаційнодидактичних умов, розробленої на таких трьох ієрархіовано-підпорядкованих рівнях: парадигмальносистемотвірна організаційно-твірна дидактична умова; комплекс організаційно-дидактичних субумов; часткові умови, що мають прогностику нескінченої варіації виявів залежно від наявної навчальної ситуації.

Проблема підготовки вчителя іноземної мови складна, оскільки формування професійної компетентності багатогранний процес. Стосовно самостійної роботи студентів важливо враховувати, що в кожному із видів діяльності основним фактором, який збуджує інтерес і прояв активності, $є$ внутрішній. Ніяка діяльність не може бути успішною, якщо в ній немає основи для особистого інтересу.

Реалізація діяльнісного підходу в процесі організації самостійної роботи не заперечує особливості інших підходів, а, навпаки, нове бачення діяльнісного підходу грунтується на контамінаційній єдності важливих аспектів компетентнісного, комунікативного, синергетичного, рефлексійного, аксіологічного, акмеологічного, культурологічного, системного та особистісно зорієнтованого, що забезпечує дидактичнозумовлену результативність впливу на формування професійної компетентності майбутнього вчителя іноземної мови на грунті статистично значущого підвищення ефективності формування їхніх суб'єктних якостей як результату активації процесів самоактуалізації та самодіяльності в інформаційно-освітньому середовищі сучасного педагогічного закладу вищої освіти.

Результати спостережень засвідчують позитивну динаміку рівня розвитку загального інтелекту студентів експериментальних груп, показники мотиву саморозвитку вищі на 13,2 \%, 
різниця рівня творчого потенціалу студентів експериментальних груп вища на 32,3 \%, ніж контрольних груп, середній рівень самооцінки вищий на 14,1 \%, значно зріс рівень сили волі студентів експериментальних груп.

Пошуки подальших досліджень вбачаємо у розробці нових аспектів організації самостійної роботи студентів, що забезпечують саморозвиток, самовдосконалення особистості.

\section{ЛІТЕРАТУРА}

1. Каплінський В. Методика викладання у вищій школі: навчальний посібник. Київ: КНТ, 2017. C. 34 .

2. Коменский Я. А. Избранные педагогические сочинения. Москва: гос. Учебно-педагогическое изд-во Мин. Просв. РСФСР, 1955. С. 272.

3. Кочина Л. Організація та зміст самостійної роботи студетів. Початкова освіта. 2009. №11, c. $20-22$.

4. Леонтьев А. О некторых психологических вопросах сознательности учения. Хрестоматия по педагогической психологии. Москва: Междунар. пед.академия, 1995. С.12.

5. Малихін О. Мотиваційно-цільовий компонент самостійної навчальної діяльності студентів вищого педагогічного навчального закладу. Радянська школа. 2005. №8, С. 28-30.

6. Малихін О. Особистість студента як суб'єкт самостійної навчальної діяльності в умовах вищого педагогічного навчального закладу. Педагогіка вищої та середньої школи: зб. наук. пр./Під ред. проф. В. К. Буряка. Кривий Ріг: КДПУ, 2005. Вип.11. С.29-44.

7. Шмир М. Акмеологічні аспекти реалізації діяльнісного підходу у процесі підготовки вчителя іноземної мови: монографія. Тернопіль: посібники і підручники. 2018. С.17-18.

8. Шмир М. Дидактичні основи реалізації діяльнісного підходу в процесі підготовки вчителя іноземної мови: автореф. дис. . . .д.пед.наук:спец.13.00.09 - теорія навчання. Тернопіль 2020. 36 с.

\section{REFERENCES}

1. Kaplinskyi, V. (2017). Metodyka vykladannia u vyshchii shkoli: navchalnyi posibnyk [Methods of teaching in high school: a textbook]. Kyiv, p. 34. [in Ukrainian].

2. Komenskiy, Ya. A. (1955). Izbrannye pedagogicheskie sochineniya [Selected pedagogical writings]. Moscov, p. 272. [in Russian].

3. Kochyna, L. (2009). Orhanizatsiia ta zmist samostiinoi roboty studetiv [Organization and content of independent work of students]. Primary education. No.11, pp. 20-22. [in Ukrainian].

4. Leontev,A. (1995). Onektorykh psikhologicheskikh voprosakhsoznatelnostiucheniya[On some psychological issues of the consciousness of teaching]. Reader on educational psychology. Moscov, p.12. [in Russian].

5. Malykhin, O. (2005). Motyvatsiino-tsilovyi komponent samostiinoi navchalnoi diialnosti studentiv vyshchoho pedahohichnoho navchalnoho zakladu [Motivational and target component of independent educational activity of students of higher pedagogical educational institution]. Soviet school. No. 8, pp. 28-30. [in Ukrainian].

6. Malykhin, O. (2005). Osobystist studenta yak subiekt samostiinoi navchalnoi diialnosti v umovakh vyshchoho pedahohichnoho navchalnoho zakladu [The student's personality as a subject of independent educational activity in the conditions of higher pedagogical educational institution]. Pedagogy of higher and secondary school: coll. Science. works. (Ed.).V. K. Buriak. Kryvyi Rih, Vol.11. pp.29-44. [in Ukrainian].

7. Shmyr, M. (2018). Akmeolohichni aspekty realizatsii diialnisnoho pidkhodu u protsesi pidhotovky vchytelia inozemnoi movy: monohrafiia [Acmeological aspects of the implementation of the activity approach in the process of training a foreign language teacher: a monograph]. Ternopil, pp.17-18. [in Ukrainian].

8. Shmyr, M. (2020). Dydaktychni osnovy realizatsii diialnisnoho pidkhodu v protsesi pidhotovky vchytelia inozemnoi movy [Didactic bases of realization of the activity approach in the course of preparation of the teacher of a foreign language]. Extended abstract of Doctor's thesis. Ternopil, 36 p. [in Ukrainian].

Стаття надійшла до редакції 16.03.2021

\section{G58080ल2058080}

"Фосконалість - ие не тоді, коли нічого додати, а тоді, коли нічого відняти". Антуан де Сент-Еқзюоері бранцузький письменник

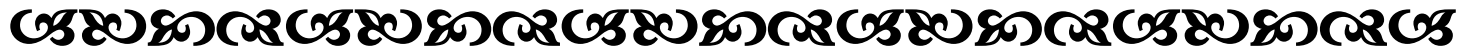

